Mariya Stankova ${ }^{1}$

South-West University "Neofit Rilski",

Faculty of Economics, Bulgaria

Ivanka Vasenska ${ }^{2}$

South-West University "Neofit Rilski",

Faculty of Economics, Bulgaria
SCIENTIFIC REVIEW ARTICLE

doi:10.5937/ekonomika1503043S

Received: May 30, 2015

Accepted: August 31, 2015

\title{
COMPETITIVENESS AND TOURISM DEVELOPMENT - IN SEARCH OF POSITIVE IMAGE-REPRESENTATIONS OF BULGARIA AS A DESTINATION
}

\begin{abstract}
Choosing the holiday destination and formatting a preference for it is based on a recognizable image, a good reputation, awareness of the main competitive advantages of a destination, and hence - the importance of this image and reputation for the competitiveness of tourist destinations. The image is an important, significant part of the tourist destination, on how to present to an international audience, but also what influences consumer's preferences. Considering this, the study examines the concept of forming an image of Bulgaria as a holiday destination, in its social and psychological perspectives. And has the following objectives: (1) to propose the formation of a positive image of Bulgaria as a tourist destination, and (2) to put the focus on Thracians culture heritage. Built on the findings that regrettably, the positive initial image of Bulgaria as a tourist destination, differs from the actual experience of tourism services for consumers.
\end{abstract}

Keywords: tourism, destination, image, competitiveness, historical and cultural heritage

JEL classification: L8, L10, L110

\section{КОНКУРЕНТНОСТ И РАЗВОЈ ТУРИЗМА - У ПОТРАЗИ ЗА ТВРДЫОМ О ПОЗИТИВНИМ ИМЏУ БУГАРСКЕ КАО ДЕСТИНАЦИЈЕ}

\begin{abstract}
Апстракт
Избор дестинащије за годишњи одмор и уочавање предности заснивају се на препознатььивом имицу, доброј репутацији, свести о главним конкурентским предностима дестиначије, тиме значај ове слике и репутащије која се односи на конкурентне туристичке дестинације је велики. Слика је важан
\end{abstract}

\footnotetext{
${ }^{1}$ mzlstan@yahoo.com

2 ivankav48@gmail.com
} 
u значајан део туристичке дестинације, о томе како је представити међународној публици, али и оно што утиче на преференције потрошача. $С$ обзиром на то, у раду се испитује концепт формирања слика Бугарске као дестинације за одмор, у њеним сочијалним и психолошким перспективама. И има следеће циљеве: (1) да предложи формирање позитивног имица Бугарске као туристичке дестинације, и (2) да стави фокус на Трачанско културно наслеђе. Рад је урађен према резултатима који нажалост, разликују почетну позитивну слику Бугарске као туристичке дестинације, од стварног искуства туристичких услуга које се пружају потрошачима.

Кључне речи: туризам, дестинација, слика, конкурентност, историјско и културно наслеђе

\section{Introduction}

Tourism, as claimed by Pearce and Stringer (1991), is essentially a sociopsychological phenomenon. For example, the interaction between tourists and residents of tourist destinations can be viewed as the interaction between two groups of people who share similar values and cultures in their own groups (Pearce, 2005). On the other hand, in the literature of social psychology quite amply is documented that the group members are often exposed to similar models of social information that could lead to collective perceptions of that group (people who we see as "different" from us) or those from foreign countries (Alexander, Brewer and Herman 1999, p. 78-93; Rubin and Hyustoun, 2004; Stangot and Lange, 1993, p. 361). Therefore, the formation of the image of a tourist destination can also be a social psychological process influenced by social factors, such as national or racial/ ethnic backgrounds of potential tourists (McKay and Fesenmayer, 2000; Prentic, 2006; Tashi and Gartner, 2007).

This study examines the concept of forming an image of a holiday destination Bulgaria, and the social and psychological perspective. Although the image of the destination of tourists is one of the important issues in the tourism literature (Tashi and Gartner, 2007), many researchers consider it as subjective and secondary meaning, without taking into account the importance of socio-cultural factors in the process of its formation (Tashi, 2009).

Therefore, it is important to consider tourist destination image formation of social and psychological point of view, since social perceptions may be biased against reality (Alexander, Brewer and Herman, 1999). For example, when the difference between the culture of the local population and that of visiting tourist isn't huge, the image of the destination can be positively influenced (Prentice, 1998). Furthermore, the formation of destination image can be negatively affected if the tourists have a negative perception of the host community and destination (Chen, Lin, and Petric, 2012; Nadeu and al, 2008). We should mention here that it is necessary for science and business to address social preconceptions about tourist destination perceptions. In fact, tourist destination trend marketers aim deliberately to create positive preconceived notions about their destinations by investing in special campaigns (Tasci, Gartner, and Cavusgil 2007). However, creating a positive image of a tourist destination, which is in turn the capital and labour intensive (Fakeye and Crompton, 1991), 
particularly when pre-existing negative images of destination are widely perceived as real in the generating tourist region (Chen, Lin and Petrick, 2012; Tasci, Gartner, and Cavusgil 2007). Given that negative destination preconceptions can erect insurmountable barriers to its marketing, this study attempts to explore how biased perceptions are socially constructed in the context of international tourism.

In particular, marketing researchers have long been interested in the effect of country stereotype, which suggests that the evaluations of customers for products manufactured in one country (the image of the product/service) may be influenced by their overall assessment of this country - image of the state (Knight and Kalatone 2000, LaRoche et al., 2005). The effect of country stereotype has also been a research subject in tourism study by researchers in tourism and the results are validated and described tourism literature (Elliott, Papadopoulos, and Kim 2011; Nadeau et al 2008). Therefore, the negative image of a country can lead to negativity impact on perceptions of it as a destination. However, considering the country's image as a precursor to the image of it as a tourism destination, as the model explains only the image, but doesn't explain when and why negative preconceptions were formed.

Social identity theory (Tajfel and Turner, 1979) may shed light on the formation of biased perceptions of the destination in the context of international tourism. According to the theory, the context of the group (or within nations) conflicts can cause people to think or act on the basis of group identities, such as ethnic identity or national identity (Turner et al., 1994). The presence of group identities, as predicted by the theory of social identity will lead to collective preconceived awareness of all group members or in our case representatives of foreign countries - international tourists (Alexander, Levin, and Henry, 2005; Herrmann et al., 1997; Rubin and Hewstone, 2004). Based on social identity theory, it is assumed that national identities in the country guests are source of the perceived image of the host country destination.

Therefore, this study has the following objectives: (1) to propose the formation of a positive image of tourist destination Bulgaria, and (2) to put the focus on Thracian culture heritage.

As the results of previous studies indicate, tourist destination's image can be influenced by previous tourists stays (Baloglu 2001; Fakeye and Crompton 1991; Hu and Ritchie 1993), for this purpose, we are quoting search below, based on the Bulgarian and foreign tourist experience in tourist destinations such as Bulgaria. Furthermore, with this study, we attempt (3) to clarify the effects of interactions between host's national identity and visitors' experience of the destination.

\section{Theoretical background}

The image is a term derived from the Latin "imago" and is associated with other Latin word -"imitari", "imitate", "emulate". This translation specifies the genesis of the term "image" - it is the result of diverse, taken from different sources, most often mediated information about real-world objects and phenomena. The image creates a second reality, but strongly affects the process of decision making from the tourist/consumer (Krstić, Krstić, and Ivanović, 2013). 
Due to the fact that economics examines the tourism sector, including products/services as intangible products, the only way tourists are 'shopping' for a holiday experience that is available through the image of tourist destinations (Um and Crompton, 1990). Therefore, for some time, tourism researchers explored approaches conceptualizing the image of the destination (Tashi, Gartner and Kavusgil, 2007) and methods for its measurement (Govars, Go, and Kumar, 2007). In addition, more recent studies examine the original image, with the intention to clarify the method by which the positive image of tourist destinations is built (Baloglu and Mac Kleariy 1999; Beerli and Martin 2004; Pearce 2006). However, the prevailing view that scientists in the field are willing to accept is that the formation of an image is an individual process, studies that have been made, identify the several personal factors such as motivation to travel (Baloglu and Mac Cleary 1999; Beerliand Martin 2004; Hsu, Cai, and Li 2010), knowledge of the destination (Baloglu 2001; Baloglu and Mac Cleary 1999; Lee, Scott and Kim 2008), and the previous visit (Beer and Martin 2004; Hyun and Purdue 2010).

Marketing specialists are interested in the concept of the image of holiday destination, mainly because it relates to making a decision on the purchase of a tourism product and the sale of related travel products and services. According to Mac Innis and Price (1987), images penetrate the whole consumption and experience.

Before purchasing an actual tourist vacation, its image can easily replace the actual consumption. During consumption, the image can add value to the experience and increase tourists' satisfaction. After consumption, the image may have reconstructive role in which the tourists can relive their experiences through holiday memories and souvenirs. The perception of various images which visitors and non-visitors have of destination is priceless, as it enables the typical attributes such as primary and revalued image to be included in marketing tourism planning (Selby and Morgan, 1996, p. 288). Marketers can use the stored images to increase satisfaction and to promote the repurchase of the tourism destination.

The concept of the destination image is formed on a reasoned emotional interpretation by the user to the submitted destination. This is caused by two closely related components - perceptual (sensory) / cognitive and emotional evaluation score to the user. Perceptual/ cognitive evaluations refer to the beliefs of the tourist and his/her knowledge of the subject (rating of perceived attributes of a tourist destination before being visited); emotional evaluations are associated with feelings of the individual to the tourist destination, based on its primary image that he/she has.

Formation of the image of a tourist destination. The image of a tourist destination is perceived uniquely by each person and the total image may include memories, associations and imagine that this is a tourist destination (Jenkins and MacArthur, 1996; Vitić-Cetković, Krstić, and Jovanović, 2015). Stablar (1988) divides the factors influencing destination image formation by factors of supply and demand. Demand drivers, generally corresponded to the formation of the organic image of Gunn, 1972 (representation below) and supply factors corresponded to induce the formation of the image. Figure 1 summarizes these factors of supply and demand. 


\section{Figure 1: Tourist Destination Image}

\section{SUPPLY FACTORS}

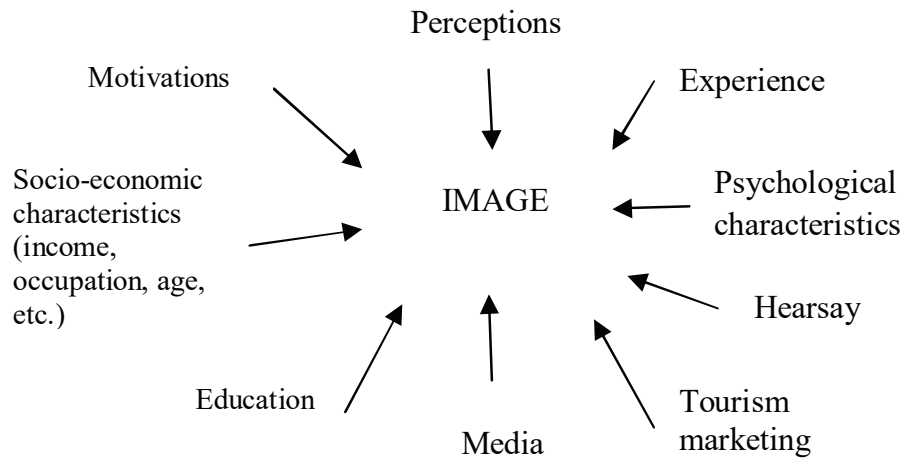

DEMAND FACTORS

Source: Jenkins, 1999.

Various researchers have investigated the factors that encourage the formation of the image of the tourist destination. For example, Nolan (1976) investigated the sources of travel information used by domestic tourists in the United States. He discovered that the source of the information used for a vocational trip often came from an advice of a friend or relative, next from tourist guides and then from advertising publications. In terms of reliability of travel information sources, tourist rated information from the guides were rated with the highest rateability, while public administration services and advice of friends and relatives were rated as the most reliable and thorough. Moreover, Nolan measured the objectivity of the sources of travel information, asking respondents to assess whether sources are biased/unbiased. What the results demonstrated is that the overall bias information was noted by respondents particularly in tourist brochures. Despite recent studies (Phelps, 1986; Stabler, 1988; Chon, 1991, 1992; Echtner and Ritchie, 1991; Botterill and Crompton, 1996; Selby and Morgan, 1996), the process of tourist destination image forming still needs a comprehensive theoretical framework.

Chon (1992) examined the effects of divergence on the one hand, between the actual and the expected image of a tourist destination and between the image and the actual tourist destination experience and the associated tourist behaviours. Furthermore, she found that a positive image and positive vocational experience can lead to moderately positive assessment of a destination, on the other hand a negative image and positive experiences can lead to greater positive evaluation of a destination. The most negative assessment would come from a positive image and negative experiences of the visited destination. In addition, measurement of the tourist travel experience has not been extensively studied (Botterill and Crompton, 1996, p. 57), thus tourism expectations and opinions are increasingly seen as important because they reflect primarily cognitive tourists, their satisfaction and their emotional reactions to a specific destination (Ross, 1993). 
Components of the tourist destination image. - From the cognitive point of view, the image of tourist destinations is based on a set of attributes/recourses which match tourists products and services available for tourists: climate; nature; culture; history; entertainment - feasible features that the destination offers tourists; events in which they participate; opportunity to become part of the culture of the place. These are called functional components.

Several studies have tried to include less tangible components of a destination image, but it is difficult to characterize psychological dimension attributes such as the atmosphere or the romance of the situation (Echtner and Ritchie, 1991). Ross (1994) commented that the only psychological variable measured, is the "friendly" attitude of the locals.

One of the major challenges that destination image studies are facing is that they are holistic and thus when researchers attempting to evaluate their representation do not comply with the constituent elements or attributes individually. Some components of the tourist destination image, however, as the atmosphere of a tourist destination due to its genesis, cannot be disassembled on constituent parts. Echtner and Ritchie (1991) bridged this challenge by offering a model that includes an attribute - holistic as one of the three dimensions. Therefore, those parts of the image of the destination, which can be defragmented to attributes and described, more or less as a holistic experience. One end of the dimension is functional and psychological qualities and on the other are functional and psychological comprehensive images related to the overall impression, the atmosphere or mood.

Figure 2 represents this model in three dimensions: attribute/holistic, functional/ psychological and common/unique. Common/unique dimension to the image presented by Ehtner and Ritchie (1991) (see Figure 2) is also often overlooked. This is surprising since largely tourism should be identified with the visit of the unique location, if not, at least, different to the daily life surroundings. Common functional attributes include traits by which most places cannot be compared (e.g. price, climate, type of accommodation). Unique functional attributes consist of "logos" and special events that are part of the image of the destination, such as Stonehenge or the music festival Glastonbury. Common psychological or abstract attributes consist of the friendliness of the locals, popularity or beauty of the landscape, while the unique attributes include psychological feelings associated with sites in religious worship or locations related to a historical event.

Figure 2: Components of the Tourist Destination Image

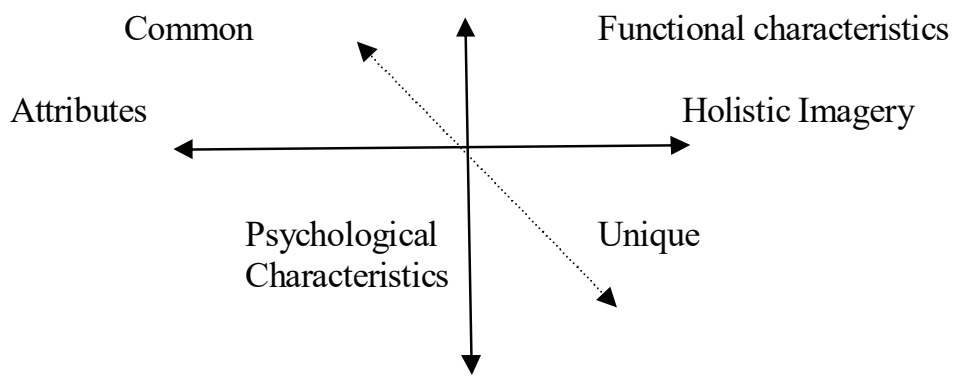

Source: Echtner and Ritchie, 1991. 
An official research, by the Bulgaria's Ministry of Economy and Energy (MEE), on the appropriate symbols and visual elements which have been detailed in order to create tourism brand Bulgaria, studied the opinion of 200 Bulgarian and 400 foreign tourists from 10 generating markets - UK, Germany, Greece, Ukraine, Russia, Serbia, Romania, Turkey, Sweden and the Czech Republic.

Bulgarian and foreign tourists who visited Bulgaria in the period $2009-2010$ (Project: "Development of a brand "Bulgaria", product and regional brands and the introduction of integrated brand management") were asked to answer a set of questions, including the following related to theresearchproblem: "What symbols and visual elements you associate with Bulgaria?", "What is Bulgaria's image among consumers?", "What disadvantages Bulgaria has as a tourist destination?". The obtained results are graphically presented in Figures 3, 4, 5 and 6.

Figure 3: Symbols and Eements Visualizing Bulgaria as a Destination for Tourists

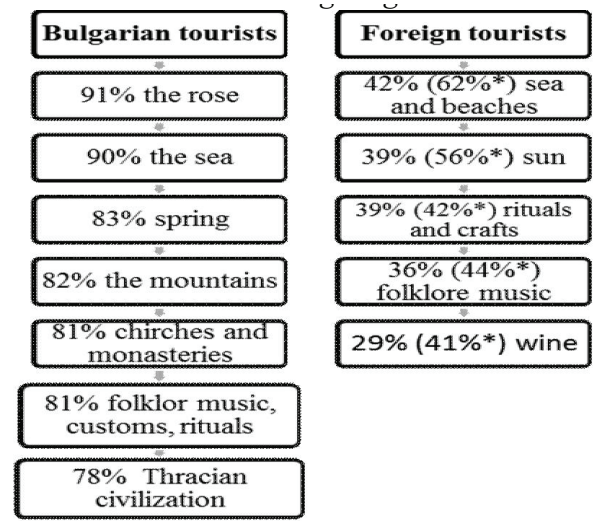

* Tourists visited Bulgaria in the last two years

Source: Ministry of Economics, Energy and Tourism, 2012

According to the Ministry, the total of 1063852 foreign tourists (except transit visitors) visited Bulgaria in the period December 2012-March 2013, which is increase of 8.2 \% compared to Winter 2011-2012. 636026 foreign tourists visited Bulgaria for leisure and recreation which is an increase of $10.4 \%$ for the period December 2012-March 2013 compared to the same period 2011-2012. 43602 arrivals of tourists visiting relatives and friends in Bulgaria which is an increase of 12.5\% for the period December 2012-March 2013 compared to 2011-2012. Revenues from international tourism for December 2012-March 2013 totalled 416.54 million euro, 4.9\%, up compared to 2011-2012 numbers for the same period. The graphic below represents Bulgaria's Image among Consumer, according to the research done by the Ministry. 
Figure 4: Bulgaria's Image among Consumer

\section{Bulgarian tourists \\ - Marvelous resources \\ - 1 Seaj \\ - 2 Mountains, \\ - 3 Climate; \\ - 4 Heritage. \\ - Inadequate tourist services; \\ - Problems with the Public Works of the country}

\section{Foreign tourists}

- Inexpensive;

- Sun;

- Inadequate tourist serv ices;

- Far away from the idea of cleanliness, safety and public works.

Source: Ministry of Economics, Energy and Tourism, 2012

The image of Bulgaria has some negative factors such as that to a certain extent the country is still viewed as a "Soviet country" (with low quality services and old establishments) and visa regime. Overall, however, Bulgaria (as a tourist destination) has a mainly positive image among consumers but also among travel agents and Journalists whom write about tourism. The most common criticism made by the tourists, according to the same research data, obtained by the Ministry, is evident below.

Figure 5: Disadvantages of Bulgaria as a tourist destination

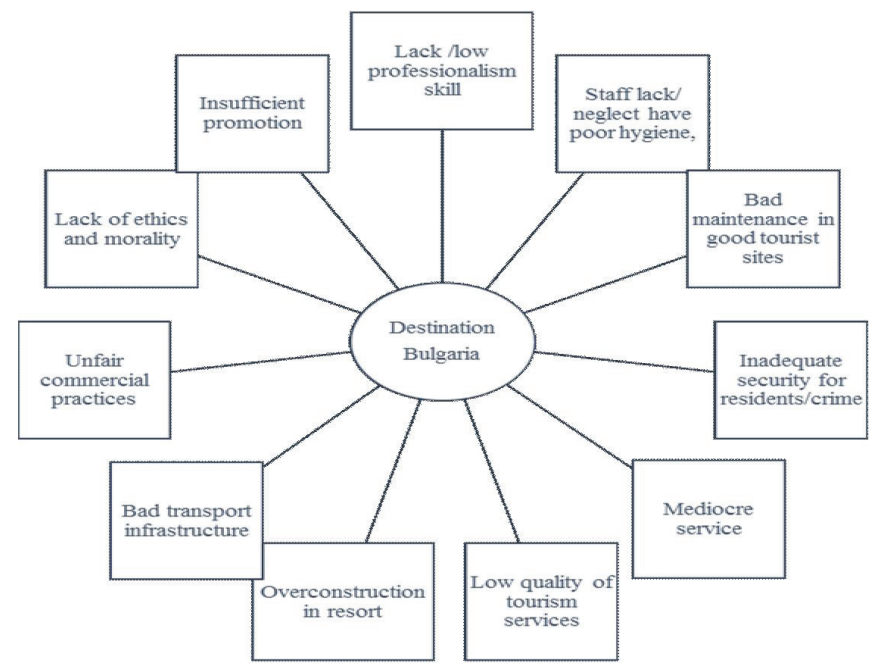

Source: Ministry of Economics, Energy and Tourism, 2012. 
We cannot disagree with Mintel Report from 2007, whom accurately observes that our rich history and the diverse landscape give vast potential for tourism in Bulgaria. Bulgaria has enjoyed a substantial growth in income from international tourism over the past decade, but despite its diversity, the mainstream beach/resort tourism and snow sports remain the major draw. There are also opportunities to develop cultural, historical, spa and ecotourism in the country. Despite the great variety of tourism assets such as mineral springs, beautiful scenery and archaeological sites, the tourism sphere remains underdeveloped. The country has yet to make the optimum of latter tourism assets, which could lead to much-needed diversification of the industry and a wider spread of tourism receipts throughout the country.

Figure 6: Top 3 Types of Tourism Practiced During the Different Seasons
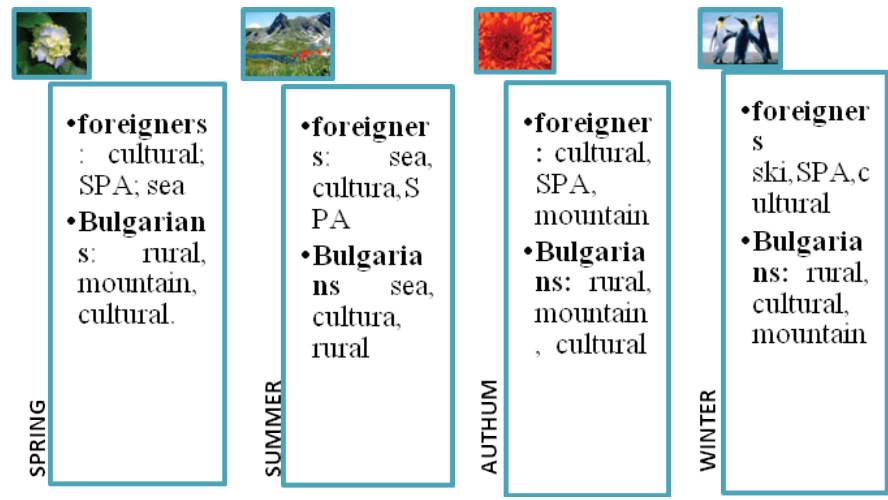

Source: "Surveys on foreign visitors to Bulgaria and of Bulgarians who travelled the country"; Ministry of Economics, Energy and Tourism, 2012

Foreign tourists have been more active, $45-66 \%$ have combined two or more types of tourism and thus have got the most out of each holiday. Bulgarian tourists appear more passive - only between $18-25 \%$ had combined two or more types of tourism, which leads us to believe that the Bulgarians have realized the need for diversity.

Table 1: Tourist's satisfaction

\begin{tabular}{|c|c|}
\hline Satisfaction factors & Dissatisfaction factors \\
\hline 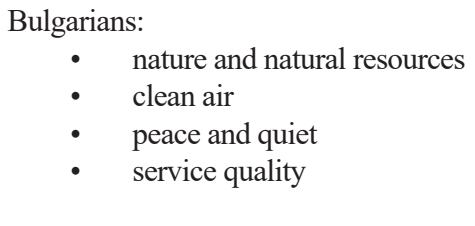 & 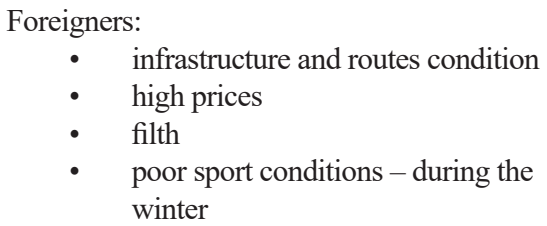 \\
\hline
\end{tabular}




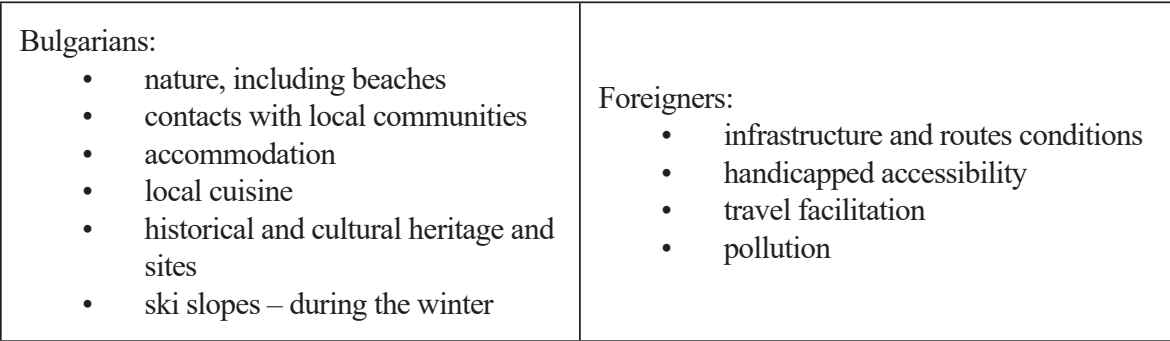

Source: "Surveys on foreign visitors to Bulgaria and of Bulgarians who travelled the country"; Ministry of Economics, Energy and Tourism, 2012

Even though tourists have remarks, they remain satisfied with their vocational stay in destination Bulgaria. Nature, clean air and good local cuisine managed to melt dissatisfaction, pollution and ill managed infrastructure. And yet - it turns out that the guests in resorts remain dissatisfied with their summer vacation - for the foreign tourist it was cheap, and for Bulgarians - expensive. Therefore, the foreign guests spend between 70 and 88 Euros per day, while the Bulgarians could afford much moderated budgets. Besides, Bulgarians felt as tourists even in their own native villages, while foreigners preferred SPA hotels and cultural tourism.

All and all, whole regions of the tourist destination remained almost unvisited and none the less the previously mentioned regions do have a potential. The number of the tourist visited the Danube region; the Old Bulgarian capitals and the Valley of the Thracian Kings were relatively small considering the high occupancy levels for the seaside and the mountains, respectively during the summer and winter.

\section{Focusing the Image on the Thracian Heritage}

In June 2007, in its section "Science", NBC published an article titled "Golden Mask, found in the tomb of a Thracian king - 2,400 years ago civilization flourished in Bulgaria", referring to the discovery of the team of Dr. Kitov near the village of Topochane. The centrepiece of the article considers the golden mask found near the town of Kazanlak in 2004 and for the first time the analogue which Kitov made between the Valley of the Thracian Kings and the Valley of the Egyptian pharaohs appeared.

In January 2010, in an article entitled "The oldest cities in the world" The Telegraph surprised the entire scientific community in Bulgaria by ranking the city Plovdiv as the sixth oldest city in the world, second only to Athens in Europe. Plovdiv, Bulgaria is ranked in another prestigious ranking - cities, which since its establishment until today were continuously inhabited. This ranking included cities of great civilizations such as Luoyang, China; Damascus, Syria; Jericho, on the West Bank of the Jordan River; Athens, Greece; Varanasi, India; Byblos, Lebanon; Ray, Iran and Jerusalem, Israel.

An exhibition entitled "The Lost World of Old Europe, the Danube Valley 5000 3500 BC" was held in Ashomolean museum, Oxford from May 20 to August 15, 2010. This was an exhibition of the oldest gold and travelled in 2010 thousands of kilometres between New York, the UK and Greece. This travelling exhibition was organized by the 
Institute of Ancient World Study at the University in New York in cooperation with the National History Museum of Romania with the participation of the Varna Archaeological Museum and the National Museum of Archaeology and History of Moldova. "1000 years older than the first cities of Mesopotamia, "Old Europe" was among the most advanced and sophisticated places in that time" wrote historians and journalists, advertising the exhibits. The culmination of the exhibition was the oldest gold in the world of the Varna necropolis. Never the less remarkable were the anthropomorphic figurines, great painted ceramics and the vast bronze objects.

In October 12, 2012 The New York Times magazine published Karen Leigh's article, entitled "In Bulgaria, Roman greatness, east of Rome" where the city of Plovdiv was described by its millennial history as one of the oldest continuously inhabited cities in the world.

The Doors of the Kings - a stretch of the River Nile Valley containing the tombs of the pharaohs of the New Kingdom, Dynasties for 18 to 20 utilized from 2nd millennium BC. For the world this is the Valley of the Kings, at least for now. It testifies to the past that the present cannot interpret. This is the largest outdoor museum in the world.

The Kazanlak valley, located in the geographic centre of destination Bulgaria is peppered with ancient tombs - dating from the 1st century BC. To all Bulgarians this is the Valley of the Kings, but only for Bulgarians, well let say so far. From outside and high mounds overgrown embankments nondescript, but over the years, their appearance has not mislead the looters, and several Thracologists. Among them at the end of 20th and beginning of the 21 st century Dr. Georgi Kitov stands out. The work of Dr. Kitov and his team began in the mid-1992.

\section{Figure 7: Kazanlak Valley}

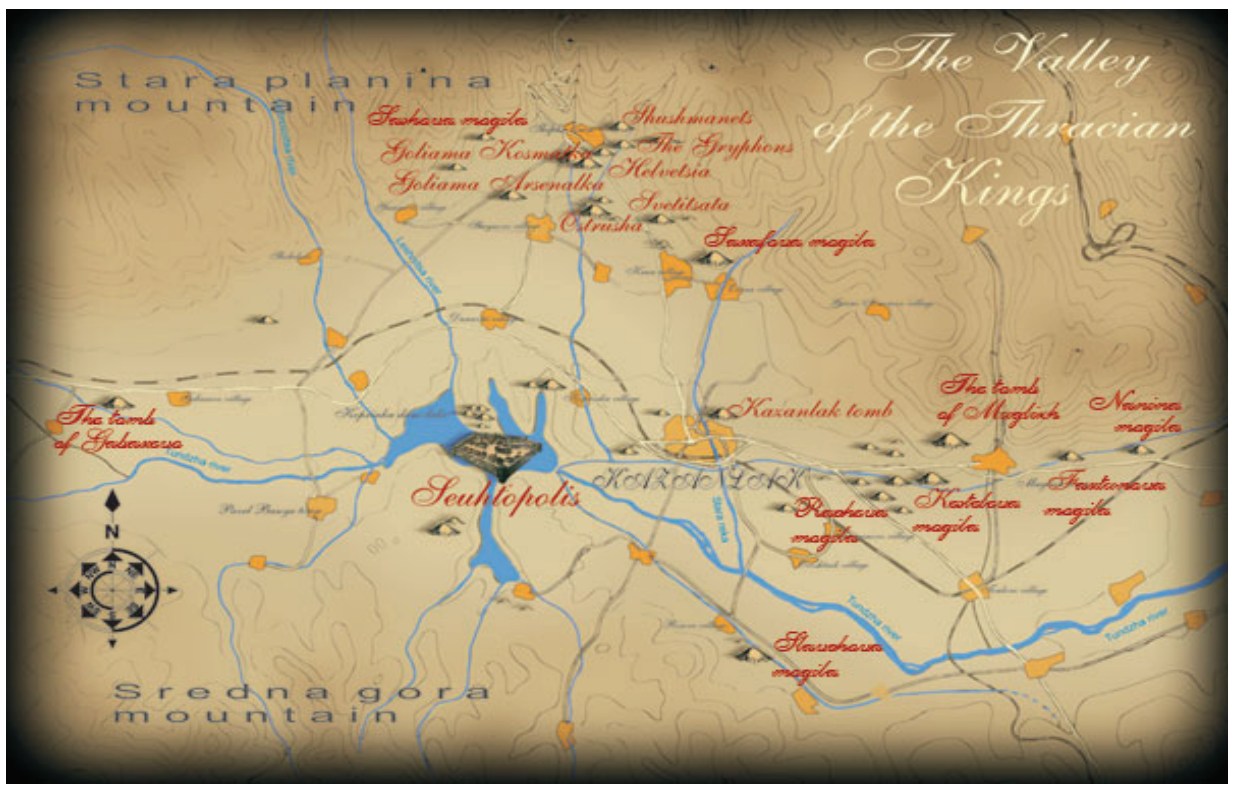

Source: http://www.kazanlaktour.com/index.php? $s=88$ 
The Valley of the Thracian Rulers is a popular name made public by the archaeologist Georgi Kitov and describes the extremely high concentration and variety of monuments of the Thracian culture in the Kazanlak Valley. It is believed that there are over 1500 funeral mounds in the region, with only 300 being researched so far.

The Kazanlak Tomb was discovered in 1944. Between 1948 and 1954 the ancient town of Seuthopolis was studied. Between the 1960s and the 1980s people made researches of the mound necropolis which belonged to residents of Sevtopolis. Another two brick tomb was found there. The Maglizh and Kran tombs were discovered in 1965. The 1960s were also marked by the research of Thracian tombs from the Roman era in the regions of the villages of Tulovo and Dabovo, made by Prof. L. Getov. During the 1970s M. Domaradski, researched a habitation and its surrounding necropolis in the Atanastsa region, village of Tazha.

The period between 1992 and 2006, with short interruptions, marked the research made by Senior Research associate G. Kitov, and the expedition TEMR (Thracian Expedition for Mound Research) led by him. As a result of their activity over 200 mounds, which represent funeral practices of the Thracians during the Iron and Roman Eras in the Kazanlak Valley, were studied. Among all monuments one can distinguish over 15 tombs in a different stage of preservation, 3 masonry graves, a lot of rich funerals, etc.

Nevertheless, one of the first accidentally discovered tombs, added in 1979 to the List of World Cultural Heritage by UNESCO and to present day and centrepiece of the Valley of the Kings is the Tomb of Kazanlak. In 1942 a tomb dated to the 3rd century BC was discovered near Kazanlak in the romantic Valley of Roses, near the ancient city of Teutopolis. The Kazanlak Tomb is a peak in the development of Hellenistic art; it is a significant contribution to the art of the entire Hellenistic world.

\section{Temple Mound "Griffins"}

The whole tomb is built of perfectly processed and precision associated with iron clamps stone blocks. The tomb was robbed in antiquity. There are also two gold beads between the stones of the bed, whose decoration is a significant archaeological value, separate gold flakes and small pieces of silver and bronze. Based on them precise dating of the tomb can be made. The construction method and plan are similar to those of the tomb mound Goliama Arsenalka.

In adjacent to Griffins - is Elenina mound where a child grave was discovered. Archaeologists found several Greek court wooden amulets in the shape of a human body, clay cult objects and other artefacts. Among them suddenly opened a small wooden box with forty coins from IV century BC. Finding as many coins in one grave is unprecedented at this time.

In the Blue mound stone heap was discovered, revealing a burial pit, approximately $5 \times 6 \mathrm{~m}$. Inside were found fifty arrowheads, full set of horse trappings, gold ring and other minor items.

The unique horse trappings are the faces of the plates covered with animal images. They are strangers from previous excavations in Thrace and are similar and those found in Southern Russia and Ukraine in the land of the Scythians. Of great value is the silver head forefront in which decoration key element is the head of a lion. The open gold ring is also unknown from previous studies. The plate depicts a cluster, turtle and gryphon. 


\section{Shushmanets Temple}

The temple in the Shushmanets mound was discovered on 28 August 1996. The temple consists of a corridor, a façade, an antechamber and a circular chamber. It was built in a previously mound earth-deposits. The corridor's walls were built from river and crushed stones, with a total of two construction stages. The façade is formed by perfectly processed granite blocks aligned in 10 rows. Once, there had been a pediment, the existence of which is proven by a semi-palmette-form antefix found during the archaeological excavations. In the façade itself, through an arch-like cutting of the blocks' internal sides, the antechamber's arch is formed. The antechamber has a rectangular form with a stone Ionic-styled column in its front centre part. Bones from six animals were found during the archaeological excavations on the premise's floor - four horses and two dogs which are believed to have been sacrificed during the funeral ceremony. Above the entrance to the central chamber, there is an embossed pediment with a palmette-shaped acrider and two antefixes in the ends. On the inside, there used to be two lacunars stone doors, decorated by indented stylized solar disks painted in red. The funeral chamber has a round shape and a vault-like cover. Its entire surface was covered with white rendering. In its centre, below the keystone, there is a fine Doric-style column. The walls are divided into three horizontal beams. The first one is divided into several fields of seven Dorianstyle semi-columns. In the chamber's northern sector, there used to be a stone bed. Based only on the architectural features of the premise, and due to the lack of precise dating archaeological, material it is difficult to make the precise dating. The tomb dates back to the 4 th century BC.

The second mound necropolis around Shoushmanetsis mound Helvetia. An ancient Thracian tomb built probably in the middle of IV century BC. Here for the first time was found reuse doors - the original was missing. Two wings of the second door that is closing the chamber were equipped with a device for closing from the inside. The east wing of the camera is painted in red and western gray-black.

The colours are deliberately chosen. Red is supposed to represent a sunrise, birth, new beginnings and the black - the sunset, the end, the death... On-site archaeologists discovered the skeleton of a horse on the altar, which blood drained on the ground through a furrow the sacrificial animal went back where it came from - in the bowels of the mother earth, and that way Thracians were able to predict the future of their people and ruler. Such a scene was found for the first time in a Thracian tomb, which proves that the facility was used as a sanctuary.

\section{Svetitsa Mound}

A masonry grave was discovered in the mound on 19 August 2004, in which a funeral of a representative of the Thracian aristocracy had taken place from the second half of the 5 th century BC. Some of the skeleton bones were found in the tomb in anatomical order, but others were missing, which makes researchers assume that the buried person had been a follower of Orpheus. The body had been laid with complete armaments - bimetal breastplate, two swords, tips for spears and arrows. As burial gifts one had placed a silver cup, a 
bronze hydria, two, probably made in Athens, dishes with red figures, two clay amphorae. Undoubtedly, the most impressive item of the funeral equipment is the gold mask, which was laid on the face of the deceased person. It was made of a solid 673-g gold plate with individual features - thick hair, beard and moustache, the eyes half-closed. This is one of the earliest and richest tombs discovered in the Valley.

In the summer of 2007 unexpected discoveries were made which completely changed the concept of the Valley of the Kings.

In Dalakovata mound in the nearby village area, the team led by Kitov, discovered another golden mask belonging probably Thracian king Teres II. Along with the mask archaeologists found several vials of gold, two ribs rhytons and numerous potteries. Like the first mask found near Kazanlak in 2004, this was originally used as a phial, and then flattened ritual for Lord can put it on your face.

\section{Ostrusha}

One of the most iconic temples discovered in the Valley of the Kings. At the southern edge of the mound in 1993 fundamentally new type of Thracian burial facility was discovered. It was built ready mound in the middle of IV century B.C. and remained some time outdoors. Originally tomb consisted of a three-stage sarcophagus chamber on a pedestal of three lines well cut stone blocks, which finished on all sides by three steps with a total height of about $0.90 \mathrm{~m}$ Thracian temple was built on an area of 100 square meters, consisting of 6 rooms, with main camera composed of a stone block weighing over 40 tons, with bilateral sloping roof weighing 20 tons. There is no explanation of how the Thracians made cluster drawings of animals, people and plants on the walls. Unfortunately, in IX century, AD the temple was totally destroyed by the local population.

\section{Golyama Kosmatka}

The monument in Golyama Kosmatka mound was found in the autumn of 2004 during regular archaeological excavations. The mound is piled up as a sacred hill in the first half of the 5th century BC. Probably in the second half of the century a monumental temple was built, consisting of a representative facade and three rooms - a rectangular one with doublepitch coverage, a round one with a dome-shaped coverage and a sarcophagus-like chamber, made of a $60 \mathrm{t}$ granite block.

At the beginning of the 3rd century $\mathrm{BC}$ in the central chamber there was a ritual burial of a Thracian aristocrat, and in the first chamber a horse sacrifice was made. Thus, the building transformed its function into a tomb.

At the facade a 13-meter corridor with stone walls and a wooden roof were built. Upon closing the facility the corridor was burnt down and filled with mound earth-deposits. Seven meters to the south of the entrance there is a head of a bronze statue - probably a portrait of a Thracian ruler. The inventory is exceptionally rich, presenting personal and grave goods made of gold, silver, bronze, alabaster, glass, clay, leather. Among the findings three subjects 
were of special interest - a bronze helmet, a silver jug and a silver cup, upon which one can read the name $\Sigma \mathrm{EY \Theta OY} \mathrm{/} \mathrm{the} \mathrm{name} \mathrm{of} \mathrm{Seuthes/.} \mathrm{This} \mathrm{fact,} \mathrm{the} \mathrm{finding} \mathrm{of} \mathrm{three} \mathrm{bronze} \mathrm{coins}$ with the image of Seuthes III at the beginning of the corridor and the extraordinary similarity of the bronze head with the images on the coins of this Thracian ruler are the reason why the discoverer G. Kitov Ph.D. makes the assumption that this is the tomb of the founder of the Thracian town Sevtopolis. Kitov argued that the head is work of Phidias, who worked in Athens during the second half of the 5th century BC. It is important evidence of the Thracian Orphic rites. This kind of discovery did not happen in the history of archaeology in Bulgaria over the last 100 years.

According to Prof. Thanos Sideris (director of "History and Archaeology" Foundation Hellenistic world), the tomb of Seuthes III is "outstanding", we cannot expect from archaeologists often to find so many riches in artefacts graves. In Greece there is only one such grave, which is believed to be of Philip II. Outside the whole range of doubt that this is indeed the tomb of Seuthes and that is one of the few, rich artefacts graves found so far." According to Dr. Sidereis and Bulgarian archaeologists, some of the artefacts may have been produced locally - made somewhere in Thrace, perhaps even in the royal court itself, by craftsmen who worked personally for the ruler. There is evidence, according Sideros that Seuthes III was in contact with many Greek cities, among which stand out his contacts with Athens. Sideris actually introduces his theory, which is been shunned in Bulgaria and is essential to world's view of the Thracians. His hypothesis is based on his joint studies with Bulgarian archaeologists (Dr. Milena Tonkova, Research Associate at AIM - Bulgarian Academy of Science and tutor in NBU) Bulgarian archeological site - "HalkaBounar."

\section{Conclusion}

Regrettably, as evidenced by the data of the above mentioned studies and research, and we as tourism services consumers of tourist destination such as Bulgaria have seen positive initial image differ from the actual experience.

In terms of demand and supply of tourism associated with Bulgaria's cultural and historical heritage, there is no study related to their anthropogenic resource identification, evaluation, protection and authentic creation of a modern tourist product that firmly stands out with its unique image. Regrettably, the Bulgaria tourist destination is associated with a negative media image of cheap, alcohol tourist destination. Furthermore, the governing authority ought to undertake new market segmentation and selection of proper market target, as we do witness a probable market niche in the cultural heritage tourism segment. Afterwards, Bulgaria's promotional campaigns need to involve the image of our rich Thracian cultural heritage. Lately has been observed a deteriorating territorial concentration and disparities in tourist location.

Overall, inadequate state of the common and specialized infrastructure, roads, drains, wastewater treatment plants, and common communications have been observed. Notwithstanding the possibility of year-round attendance at cultural tourism sites, there is seasonal demand and limited diversification of the tourism product, reduced average length of stay and lower average room revenue from tourists. 


\section{References}

Alexander, Michele G., Marilynn B. Brewer, and R. K. Herrmann. (1999). Images and Affect: A Functional Analysis of Out-Group Stereotype. Journal of Personality and Social Psychology, 77 (1), 78-93.

Baloglu, S. (2001). Image variations of Turkey by familiarity index: informational and experiential dimensions. Torism Management, 2, 127-133.

Beerli, A. and Josefa D. M. (2004). Factor Influencing Destination Image, Annals of Tourism Research, 31 (3),657-81.

Botterill, T. D., and Crompton, J. L. (1987). Personal constructions of holiday snapshots, Annals of Tourism Research, 14, 152-156.

Botterill, T. D., and Crompton, J. L. (1996). Two case studies exploring the nature of the tourist's experience, Journal of Leisure Research, 28 (1), 57-82.

Chen, Chun-Chu, Yueh-Hsiu Lin, and James F. Petrick. (2012). International Stereotype and the Collective Construction of Destination Image, Tourism Analysis, 17 (1), $55-$ 66.

Chon, K. S. (1990). The role of destination image in tourism: a review and discussion, Tourist Review, 2, 2-9.

Chon, K. S. (1991). Tourism destination image modification process - marketing implications, Tourism Management, 12, 68-72.

Chon, K. S. (1992). The role of destination image in tourism: an extension, Tourist Review, 2, 2-7.

Collier, J. (1967).Visual Anthropology: Photography as a Research Method. New York: Holt, Reinhart and Winston.

Echtner, C. M., and Ritchie, J. R. B. (1991).The meaning and measurement of destination image, Journal of Travel Studies, 2(2), 2-12.

Fakaye, P.C. \& Crompton, J.L. (1991). Image differences between prospective, firsttime and repeat visitors to the lower Rio Grande valley, Journal of Travel Research, 30 (2), 10-16.

February 2007, London.

Govers, R., Frank M. Go, and K. Kumar. (2007). Promoting Tourism Destination Image, Journal of Travel Research, 46 (1), 15-23.

Gunn, C. A. (1972).Vacationscape - Designing Tourist Regions. Austin, Texas: University of Texas.

Hsu, Cathy H. C., Liping A. Cai, and Mimi Li. (2010). Expectation, Motivation, and Attitude: A Tourist Behavioural Model. Journal of Travel Research, 49 (3), 282-96. http://www.mi.government.bg/files/useruploads/files/vop/brand_research.pdf

$\mathrm{Hu}$, Y., and B. J. R. Ritchie (1993). Measuring destination attractiveness: A contextual approach, Journal of Travel Research, Vol. 32, No. 2, 25-34.

Hyun, S. S., and Richard R. Perdue. (2010). Previous Trip Satisfaction, Destination Images, and Probability of Future Visitation.” Tourism Analysis, 15 (6), 725-28. 
Jenkins, O. H. (1993). Marketing and the ecotourism paradox. Sydney: University of Sydney Honours Thesis, submitted in partial fulfillment of the Bachelor of Economic (Social Sciences), Department of Geography.

Jenkins, O. H., and McArthur, S. (1996).Marketing Protected Areas, Australian Parks and Recreation, 32(4), 10-15.

Krstić, B., Krstić, S., \& Ivanović, V. (2013). Identitet, imidž i reputacija-determinante konkurentnosti preduzeća. Ekonomika, 59(1), 26-35.

Lee, S., D. Scott, and H. Kim. (2008). Celebrity Fan Involvement and Destination Perceptions. Annals of Tourism Research, 35 (3), 809-32.

Lin, Y.-H., Ch. Chen, and Ch. Wong Park. (2012). The Salient and Organic Images of Taiwan as Perceived by Mainland Chinese Tourists. Asia Pacific Journal of Tourism Research, 17(4), 381-393.

MacInnis, D. J., and Price, L. L. (1987). The role of imagery in information processing: review and extension, Journal of Consumer Research, 13, 473-491.

Mackay, Kelly J., and Daniel R. Fesenmaier. (2000). “An Exploration of Cross-Cultural Destination Image Assessment. Journal of Travel Research, 38 (4), 417-23.

Ministry of Tourism, Project: Development of a brand "Bulgaria", product and regional brands and the introduction of integrated brand management developed by "Unification of Bulgaria brand.

Mintel International Group Ltd. (2007), Country Reports No.1, Europe, Travel \& Tourism Intelligence,

Nadeau, J., L.Heslop, N. O’Reilly, and P.Luk. (2008). Destination in a Country Image Context, Annals of Tourism Research, 35 (1), pp. 84-106 in: Pearce, Philip L. (2005). Tourist Behavior: Themes and Conceptual Schemes. Buffalo, NY: Channel View.

Nolan, D. (1976).Tourist's use and evaluation of travel information, Journal of Travel Research, 14, 6-8.

Prentice, R. (2006). Evocation and Experiential Seduction: Updating Choice-Sets Modeling, Tourism Management, 27 (6), 1153-1170.

Prentice, R.C., Witt, S.F. \& Hamer, C. (1998). Tourism as experience. The case of Heritage Parks. Annals of Tourism Research, 25(1), 1-24.

Ross, G. F. (1993).Ideal and actual images of backpacker visitors to Northern Australia. Journal of Travel Research, 21(3), 54-57.

Ross, G. F. (1994).The Psychology of Tourism. Melbourne: Hospitality Press.

Rubin, M and Hewstone, M. (2004). Social Identity, System Justification, and Social Dominance: Commentary on Reicher, Jost et al., and Sidanius et al., Political Psychology, 25 (6), 823-44.

Selby, M., and Morgan, N. J. (1996), Recognising place image - a case-study of its role on destination market research, Tourism Management, 17(4), 287-294.

Stangor, Ch., and J. Lange. (1993). Mental Representations of Social Groups: Advances in Understanding Stereotypes and Stereotyping., In Advances in Experimental Social Psychology, Vol. 26, edited by Mark P. Zanna. New York: Academic Press, 357-416. 
Tasci, Asli D. A., and W. C. Gartner. (2007). Destination Image and Its Functional Relationships, Journal of Travel Research, 45 (4), 413-425.

Um, S. and Crompton J. L. (1999). The Roles of Image and Perceived Constraints at Different Stages in the Tourist's Destination Decision Process" In A. Pizam, Y. Mansfeld (Eds.). Consumer Behaviour in Travel and Tourism (pp. 81-102). New York: Haworth Press.

Um, S. and Crompton J.L. (1990). Attitude Determinants in Tourism Destination Choice. Annals of Tourism Research, 17(3), 432-448.

Vitić-Cetković, A., Krstić, B. and Jovanović, I. (2015). Improving the tourism destination image with intangible cultural heritage: Montenegro as a Case Study. Ekonomika, 61(2), 29-37. 